\title{
Responses of Common Bean (Phaseolus vulgaris L.) Plants to Treatment with Industrial Ceramic-Waste Water Sludge
}

\author{
Ghada Salem Sasi ${ }^{(1)}$, Nesma M. Helal ${ }^{(2)}$, Magda M. El-Araby(2) \\ (I) Botany Department, Faculty of Science, Omar Al-Mukhtar University, Derna, \\ Libya; ${ }^{(2)}$ Botany Department, Faculty of Science, Ain Shams University, Cairo, Egypt.
}

\begin{abstract}
THIS STUDY aimed to investigate the physiological and biochemical responses of common bean (Phaseolus vulgaris L. cv. Valentino) plants grown in virgin sandy soil incorporated with ceramic wastewater sludge (CWWS), at relatively low concentrations $(0.5 \%, 1 \%$ and $2 \%)$, for 30 days. Within the different levels used of CWWS, especially at $1 \%$, the enhancement of plants growth was generally proportional with the increase in leaf area and chlorophyll content, as well as it associated with higher uptake of $\mathrm{P}, \mathrm{N}$ and $\mathrm{K}$ due to higher content of these metals in the CWWS- amended soil. Sucrose, proline and malondialdehyde (MDA) showed enhanced levels with the increase of CWWS application, while, glutathione (GSH) content of common bean plants showed attenuated levels. These results were in alliance with accumulation of higher levels of $\mathrm{Fe}$ and $\mathrm{Cu}$ metals inside the plant tissues. Antioxidant enzymes such as catalase (CAT), polyphenol oxidase (PPO), showed significantly enhanced activities with increasing the amended ratio of sludge. This increase was also accompanied with the increase in ascorbic acid (AsA) and total phenol contents and a decrease in the activities of ascorbate oxidase (ASO) and ascorbate peroxidase (APX).
\end{abstract}

Keywords: Ceramic- wastewater sludge, Chlorophylls, Common bean, Heavy metals, Metabolites

\section{Introduction}

Edible dry bean or common bean (Phaseolus vulgaris L.) is an annual herb that is considered as one of the most highly cultivated legumes. It is a primary source of protein, fiber and vitamins in developing nations (Chaoui et al., 1997).

Accumulation of heavy metals may adversely affect soil ecology, agriculture production, ground water quality and will ultimately harm living organism due to the probability of food contamination through the soil root interface.

Ceramic waste-water sludge is referred to as a precipitate of turbidity and suspended solids of ceramic industry wastewater. Being rich in organic and inorganic plant nutrients, ceramic sludge is usually disposed into sanitary-landfills, causing serious environmental problems. It also results in availability of potential toxic heavy metals such as cadmium, chromium, copper, zinc, iron, boron, etc., which needs to be considered and often restricts its uses (Elias et al., 2014). Excessive accumulation of heavy metals in agricultural soils through ceramic sludge amendment, may not only result in soil contamination, but also would lead to elevated heavy metal uptake by crops, and thus affects food quality and safety (Muchuweti et al., 2006).

Reduction of growth has been recorded in plants growing under heavy metal polluted soils as a result of changes in physiological and biochemical processes (Chatterjee \& Chatterjee, 2000). Meanwhile, sewage sludge was found to increase the dry weight and yield of maize, sunflower and barley plants (Singh \& Agrawal, 2008). Antolín et al. (2010) also demonstrated that the addition of moderate doses of sludge to soil in alfalfa plants, led to an enhancement of the net photosynthetic rate and leaf conductance that resulted in higher dry matter accumulation and high photosynthetic products. In addition, Kotb et al. (2012) recommended enhanced growth of peppermint plant irrigated with ceramic wastewater. However, these beneficial effects on vegetation depend on several parameters including sludge composition, processing and application mode, as well as soil physical characteristics and climatic factors (McBride, 2003). 
Heavy metals cause injury at cellular level by the formation of free radicals. Studies showed that osmotic regulations in tolerant plants have occurred through higher accumulation of osmo- protectants (Hossain \& Fujita, 2010; Ranganayakulu et al., 2013 and Filippou et al., 2014).

Plants have evolved a complex system of both enzymatic and non-enzymatic defense mechanisms against deleterious effects of heavy metal-induced oxidative stress. Non-enzymatic antioxidant molecules include ascorbic acid (AsA), reduced glutathione (GSH), carotenoids, and phenolic compounds (e.g., flavonoids, tannins, lignins) that act as free radical scavengers (Brown et al., 1998 and Lavid et al., 2001). Enzymatic antioxidant defenses include superoxide dismutase (SOD), peroxidase (POX) and catalase (CAT), as well as ascorbate peroxidase (APX) that are designed to scavenge superoxide radical and hydrogen peroxide (Hernández et al., 2001).

Despite the above-mentioned interest on ceramic sludge, its use as fertilizer is still currently under debate since it contains high concentrations of several potentially harmful contaminants that may result in risks to plants and humans (Adamcová et al., 2016). Thus, the present study aimed to examine the physiological and biochemical responses of common bean (Phaseolus vulgaris L.) plants to cultivation in sandy soil amended with industrial ceramic wastewater sludge. The results would evaluate its possible application and then its contribution to waste recycling in Egypt.

\section{Materials and Methods}

\section{Materials}

Seeds of Phaseolus vulgaris L. (cv. Valentino) were obtained from Vegetable Crops Seed Production and Technology Department, Horticulture Research Institute, Agriculture Research Center, Giza, Egypt. The ceramic wastewater sludge (Table 1) was collected from a drainage outlet of ceramic industrial factory in Abou- Zaabal, Egypt. The chemicals used were pure (AR) purchased from Sigma-Aldrich.

\section{Methods}

Seeds were surface sterilized by immersing in $1 \%$ sodium hypochlorite solution for $5 \mathrm{~min}$, then rinsed thoroughly with distilled water. A pot experiment was conducted in the Botanical Garden of the Department of Botany, Faculty of Science,
Ain Shams University. Ceramic wastewater was incorporated to sandy soil at different levels $(2 \%$, $1 \%$ and $0.5 \%$ sludge).Sandy soil $100 \%$ represented the control. Pots $(40 \times 60 \mathrm{~cm})$ each containing $15 \mathrm{~kg}$ of the respective soil were used. The sterilized seeds were sown in the pots and then further irrigated with a constant amount of water until 30 days after planting. This experiment was carried out in a complete randomized design with three replicates per treatment. The plants were exposed to normal day length with natural temperature (about $22 / 13 \pm 2^{\circ} \mathrm{C}$ and $11 \mathrm{hr}$ photoperiod). Thinning was carried out after 10 days leaving seedlings of uniform growth rate. The young plants were collected after 30 days from sowing. Ten different samples from each treatment were taken for measuring of growth parameters. Moreover, three different samples were collected for analyses of photosynthetic pigments, soluble sugar, sucrose, soluble protein, proline, malondialdehyde (MDA), minerals as well as enzymatic and non-enzymatic antioxidants.

TABLE 1. Initial analysis of the ceramic sludge (\%) before cultivation.

\begin{tabular}{lc}
\hline Mineral ion & Concentration (\% w/w) \\
\hline Iron $(\mathrm{Fe})$ & 1.77 \\
Zinc $(\mathrm{Zn})$ & 0.65 \\
Lead $(\mathrm{Pb})$ & 0.04 \\
Calcium $(\mathrm{Ca})$ & 1.93 \\
Magnesium $(\mathrm{Mg})$ & 0.25 \\
Sodium $(\mathrm{Na})$ & 1.59 \\
Potassium $(\mathrm{K})$ & 1.01 \\
Aluminum $(\mathrm{Al})$ & 8.33 \\
Silicon $(\mathrm{Si})$ & 29.47 \\
\hline
\end{tabular}

Extraction and estimation of photosynthetic pigments

Photosynthetic pigments (chlorophylls $a \& b$ and carotenoids) were extracted in $80 \%$ acetone and determined spectrophotometrically as mentioned by Metzener et al. (1965).

\section{Extraction and estimation of some osmolytes}

Total soluble sugars were determined using anthrone method (Fairbairn, 1953). Soluble protein contents were measured using FolinCicalteu reagent according to the procedure described by Daughaday et al. (1952). Proline was determined by using acid ninhydrin reagent according to the method of Bates et al. (1973).

Non enzymatic antioxidants

Water soluble antioxidants such as glutathione, 
ascorbic acid and total phenols were determined by the methods of Griffith (1980), Kampfenkel et al. (1995) and Makkar et al. (1993), respectively.

\section{Lipid peroxidation}

Indication of membrane damage was estimated by measuring the amount of malondialdehyde, using the thiobarbaturic acid reaction, as described by Minotti \& Aust (1987).

Extraction and estimation of antioxidant enzymes

The method adopted for enzyme extraction was that described by Mukheriee \& Choudhuri (1983). Superoxide dismutase (SOD EC 1.15.1.1) activity was determined by using the method described by Marklund \& Marklund (1974). Catalase (CAT EC 1.11.1.6) activity was assayed according to the method of Chen et al. (2000). Peroxidase (POX EC 1.11.1.7) and polyphenol oxidase (PPO EC 1.10.3.1) activities were assayed following the method of Kar \& Mishra (1976). Asorbate oxidase (ASO EC 1.10.3.3) and ascorbate peroxidase (APX EC 1.11.1.1) activities were measured according to the method described by Diallinas et al. (1997) and Koricheva et al. (1997), respectively.

\section{Extraction and estimation of mineral elements}

The method of extraction adopted in this investigation was essentially that of Chapman \& Pratt (1961). The mineral elements (phosphorous, iron, copper, aluminum, silicon) were measured using multi-parameter bench photometer. Sodium and potassium were determined according to the method described by Page et al. (1982). Nitrogen was measured using Kjeldal Nitrogen Distillation Assembly.

\section{Statistical analysis}

Results were expressed as mean values \pm standard error (SE). Statistical significance was tested between control and treatments using the one-way analysis of variance (ANOVA) test. Post hoc testing was performed for intergroup comparisons using the Least Significant Difference (LSD) test and a $\mathrm{P}$ value $<0.05$ was considered significant (Snedecor \& Cochran, 1980).

\section{$\underline{\text { Results }}$}

\section{Growth parameters}

There was a reduction in shoot and root lengths of young $P$. vulgaris plants grown in sandy soil incorporated with ceramic wastewater sludge at $0.5 \%$ and $2 \%$ levels, whereas a significant increment in both shoot and root lengths was obtained at $1 \%$ level (Table 2). The application of wastewater sludge at $1 \%$ level promoted the fresh and dry weights of shoots as well as the leaf area in common bean plants. On the other hand, wastewater sludge at $0.5 \%$ and $2 \%$ levels markedly reduced the fresh and dry weights of roots in the investigated plants (Table 2).

\section{Changes in photosynthetic pigments}

Data presented in Table 3 indicate that chlorophylls $a, b$ and carotenoids in the leaves of $P$. vulgaris were significantly increased at all levels of sludge amendments, as compared with corresponding control plants grown in ceramic sludge-free soil. Highest content of carotenoids was obtained at $2 \%$ sludge.

\section{Changes in osmolytes and protein content}

The industrial ceramic wastewater sludge induced reduction of soluble sugar and soluble protein contents in P. vulgaris plants, whereas sucrose and proline contents were markedly increased (Table 4).

TABLE 2. Effect of different levels (w/w) of ceramic wastewater sludge (CWWS) on growth parameters of Phaseolus vulgaris L. (cv. Valentino) plants (30-day-old) grown in sandy soil.

\begin{tabular}{lccccccc}
\hline & $\begin{array}{c}\text { Growth } \\
\text { parameters }\end{array}$ & \multicolumn{2}{c}{ Lengths (cm) } & \multicolumn{2}{c}{ Fresh weight (g) } & Dry weight (g) & $\begin{array}{c}\text { Leaf area } \\
\left.\mathbf{( c m}^{2}\right)\end{array}$ \\
\cline { 2 - 8 } & Shoot & Root & Shoot & Root & Shoot & Root & \\
\hline 0.0 & $16.6 \pm 0.82$ & $5.8 \pm 0.31$ & $4.7 \pm 0.08$ & $1.38 \pm 0.03$ & $0.45 \pm 0.02$ & $0.20 \pm 0.03$ & $0.21 \pm 0.005$ \\
0.5 & $13.2 \pm 0.50$ & $4.7 \pm 0.23$ & $3.0 \pm 0.13$ & $1.72 \pm 0.11$ & $0.24 \pm 0.008$ & $0.33 \pm 0.02$ & $0.32 \pm 0.02$ \\
1.0 & $18.0 \pm 0.28$ & $6.8 \pm 0.31$ & $3.6 \pm 0.17$ & $2.30 \pm 0.10$ & $0.32 \pm 0.03$ & $0.46 \pm 0.04$ & $0.33 \pm 0.02$ \\
2.0 & $13.0 \pm 0.33$ & $5.0 \pm 0.14$ & $1.5 \pm 0.15$ & $1.82 \pm 0.06$ & $0.19 \pm 0.01$ & $0.28 \pm 0.03$ & $0.25 \pm 0.02$ \\
LSD at $0.05 \%$ & 0.789 & 0.362 & 0.200 & 0.115 & 0.279 & 0.470 & 0.261 \\
\hline
\end{tabular}

Results are means of ten replicates \pm SE. 
TABLE 3. Effect of different levels (w/w) of ceramic wastewater sludge (CWWS) on photosynthetic pigment contents $(\mu \mathrm{g} / \mathrm{g} \mathrm{FW)}$ of Phaseolus vulgaris L. (cv. Valentino) plants (30-day-old) grown in sandy soil.

\begin{tabular}{lccc}
\hline CWWS (\%) & Chlorophyll $\boldsymbol{a}$ & Chlorophyll $\boldsymbol{b}$ & Carotenoids \\
\hline 0.0 & $307.7 \pm 7.67$ & $79.2 \pm 4.21$ & $114.1 \pm 0.03$ \\
0.5 & $448.3 \pm 34.06$ & $145.9 \pm 16.68$ & $126.8 \pm 3.25$ \\
1.0 & $506.5 \pm 21.15$ & $187.3 \pm 9.93$ & $125.3 \pm 1.38$ \\
2.0 & $411.9 \pm 14.89$ & $193.6 \pm 12.84$ & $163.1 \pm 8.68$ \\
LSD at $0.05 \%$ & 30.73 & 16.70 & 6.63 \\
\hline
\end{tabular}

Results are means of three replicates $\pm \mathrm{SE}$.

TABLE 4. Effect of different levels (w/w) of ceramic wastewater sludge (CWWS) on soluble sugars, sucrose, total soluble protein, proline and malondialdehyde (MDA) contents of Phaseolus vulgaris L. (cv. Valentino) plants (30-day-old) grown in sandy soil.

\begin{tabular}{lccccc}
\hline PWWS (\%) & $\begin{array}{c}\text { Soluble sugars } \\
(\mathbf{m g} / \mathbf{g} \text { FW) }\end{array}$ & $\begin{array}{c}\text { Sucrose } \\
(\mathbf{m g} / \mathbf{g} \text { FW) }\end{array}$ & $\begin{array}{c}\text { Total soluble } \\
\text { protein } \\
(\mathbf{m g} / \mathbf{g} \text { FW) }\end{array}$ & $\begin{array}{c}\text { Proline } \\
(\boldsymbol{\mu g} / \mathbf{g} \text { FW) }\end{array}$ & $\begin{array}{c}\text { MDA } \\
(\mathbf{n m o l} / \mathbf{g} \text { FW) }\end{array}$ \\
\hline 0.0 & $3.28 \pm 0.07$ & $2.71 \pm 0.21$ & $13.1 \pm 0.32$ & $172.5 \pm 7.99$ & $0.007 \pm 0.0003$ \\
0.5 & $1.43 \pm 0.12$ & $4.65 \pm 0.09$ & $10.9 \pm 0.17$ & $209.3 \pm 18.56$ & $0.010 \pm 0.0003$ \\
1.0 & $1.59 \pm 0.06$ & $3.35 \pm 0.15$ & $10.5 \pm 0.20$ & $292.1 \pm 28.25$ & $0.016 \pm 0.002$ \\
2.0 & $1.91 \pm 0.12$ & $3.79 \pm 0.008$ & $9.2 \pm 0.10$ & $205.3 \pm 1.51$ & $0.018 \pm 0.002$ \\
LSD at $0.05 \%$ & 0.146 & 0.235 & 0.308 & 24.58 & 0.0021 \\
\hline
\end{tabular}

Results are means of three replicates $\pm \mathrm{SE}$.

Changes in lipid peroxidation product (MAD)

The MAD content increased in $P$. vulgaris plants grown under the differently applied levels of ceramic wastewater sludge (Table 4). The highest value of MAD was recorded in the plants at $2 \%$ level, where its value was double that in the control plants $(0.0 \%$ ceramic wastewater sludge $)$.

Changes in antioxidant enzymes

As shown in Table 5, ceramic wastewater sludge resulted in a significant increase in the activities of catalase (CAT) and polyphenol oxidase (PPO) and significantly decreased the activities of superoxide dismutase (SOD), peroxidase (POX), ascorbate oxidase (ASO) as well as ascorbate peroxidase (APX) of $P$. vulgaris plants.

Changes in antioxidant compounds

The results presented in Table 6 show that the application of ceramic wastewater sludge to soil, significantly stimulated the accumulation of both ascorbic acid (ASA) and total phenol contents of $P$. vulgaris plants. However, the glutathione (GSH) levels were lower than those of the control plants.

TABLE 5. Effect of different levels (w/w) of ceramic wastewater sludge (CWWS) on the activities of some antioxidant enzymes of Phaseolus vulgaris L. (cv. Valentino) plants (30-day-old) grown in sandy soil.

\begin{tabular}{|c|c|c|c|c|c|c|}
\hline CWWA $(\%)$ & $\begin{array}{c}\text { CAT } \\
\left(\mathrm{mM} \mathrm{of} \mathrm{H}_{2} \mathrm{O}_{2} / \mathrm{g}\right. \\
\text { FW/min) }\end{array}$ & $\begin{array}{c}\text { SOD } \\
\text { (unit/mg } \\
\text { protein) }\end{array}$ & $\begin{array}{c}\text { PPO } \\
\text { (amount of } \\
\text { quinon } / \mathrm{g} \text { FW/ } \\
\text { min) }\end{array}$ & $\begin{array}{c}\text { POX } \\
\text { (amount of } \\
\text { quinon/g FW/ } \\
\text { min) }\end{array}$ & $\begin{array}{c}\text { ASO } \\
\text { (mM ascorbate } \\
\text { oxidized } / \mathrm{g} \mathrm{FW/} \\
\text { min) }\end{array}$ & $\begin{array}{c}\text { APX } \\
\text { (mM ascorbate } \\
\text { oxidized/g FW/ } \\
\text { min) }\end{array}$ \\
\hline 0.0 & $0.14 \pm 0.02$ & $5.13 \pm 0.25$ & $2.41 \pm 0.15$ & $5.85 \pm 0.008$ & $11.3 \pm 0.20$ & $8.67 \pm 0.32$ \\
\hline 0.5 & $0.24 \pm 0.008$ & $1.87 \pm 0.05$ & $4.31 \pm 0.29$ & $5.05 \pm 0.17$ & $10.3 \pm 0.17$ & $6.47 \pm 0.11$ \\
\hline 1.0 & $0.27 \pm 0.02$ & $3.18 \pm 0.16$ & $4.87 \pm 0.22$ & $5.08 \pm 0.02$ & $10.5 \pm 0.12$ & $6.91 \pm 0.12$ \\
\hline 2.0 & $0.28 \pm 0.012$ & $3.03 \pm 0.24$ & $5.98 \pm 0.33$ & $5.04 \pm 0.05$ & $10.3 \pm 0.29$ & $6.55 \pm 0.22$ \\
\hline LSD at $0.05 \%$ & 0.221 & 0.272 & 0.367 & 0.408 & 0.292 & 0.307 \\
\hline
\end{tabular}

Results are means of three replicates $\pm \mathrm{SE}$. 
TABLE 6. Effect of different levels (w/w) of ceramic wastewater sludge (CWWS) on ascorbic acid, glutathione and total phenol contents of Phaseolus vulgaris L. (cv. Valentino) plants (30-day-old) grown in sandy soil.

\begin{tabular}{lccc}
\hline CWWA (\%) & $\begin{array}{c}\text { Parameters } \\
\text { Ascorbic acid } \\
(\boldsymbol{\mu g} / \mathbf{g} \mathbf{F W})\end{array}$ & $\begin{array}{c}\text { Glutathione } \\
(\boldsymbol{\mu g} / \mathbf{g} \text { FW })\end{array}$ & $\begin{array}{c}\text { Total phenols } \\
(\mathbf{m g} / \mathbf{g} \text { FW) }\end{array}$ \\
\hline 0.0 & $2.80 \pm 0.13$ & $71.4 \pm 2.38$ & $0.83 \pm 0.21$ \\
0.5 & $3.79 \pm 0.11$ & $67.6 \pm 0.24$ & $2.33 \pm 0.09$ \\
1.0 & $3.39 \pm 0.23$ & $68.2 \pm 0.29$ & $2.08 \pm 0.15$ \\
2.0 & $4.00 \pm 0.02$ & $66.8 \pm 0.80$ & $2.06 \pm 0.008$ \\
LSD at $0.05 \%$ & 0.208 & 1.800 & 0.125 \\
\hline
\end{tabular}

Results are means of three replicates \pm SE.

TABLE 7. Effect of different levels (w/w) of ceramic wastewater sludge (CWWS) on the contents of iron (Fe),

Changes in some element contents

The levels of NPK were generally increased with the application of different levels of ceramic sludge of $P$. vulgaris plants as well as sodium $(\mathrm{Na})$ ions (Table 7). Iron (Fe), was significantly increased as compared with those of the control plants. On the other hand, inconsistent results were obvious in cases of copper $(\mathrm{Cu})$, aluminum (Al), as well as silicon ( $\mathrm{Si})$.

\section{Discussion}

Heavy metal accumulation in soils is of significant concern in agriculture due to its adverse effects on food safety and marketability, crop growth due to phytotoxicity, and environmental health of soil organisms (Nagajyoti et al., 2010). In this respect, reviews are available on heavy metal occurrence and toxicity in plants (e.g. Nagajyoti et al., 2010 and Yadav, 2010). Assessment of soil heavy metals for eco-environment and human health have been also extensively discussed (e.g.
Tian et al., 2017 and Zia et al., 2017).

The results of the present study showed that ceramic waste water sludge (CWWS) induced significant reductions in root length, fresh and dry weights of roots of 30- day-old common bean (Phaseolus vulgaris L. cv. Valentino) plants in treatment with $2 \%$ ceramic sludge. On the other hand, $1 \%$ ceramic sludge generally resulted in significantly increased growth parameter than corresponding criteria of the control plant. However, the responses to the differently applied doses of CWWS, in the present work, would be assumed to be related to the used common bean cultivar (Phaseolus vulgaris L., cv. Valentino) on one hand, and the used virgin sandy soil, on the other hand. In this respect, authors stated that different responses of plants to heavy metals exposure mainly depend on the species tolerance potential in a certain soil (Goland-Goldhirsh, 2006 and Rahman et al., 2017).

copper $(\mathrm{Cu})$, silicon $(\mathrm{Si})$, aluminum $(\mathrm{Al})$, phosphorous $(\mathrm{P})$, nitrogen $(\mathrm{N})$, potassium $(\mathrm{K})$ and sodium (Na) of Phaseolus vulgaris L. (cv. Valentino) plants (30-day-old) grown in sandy soil.

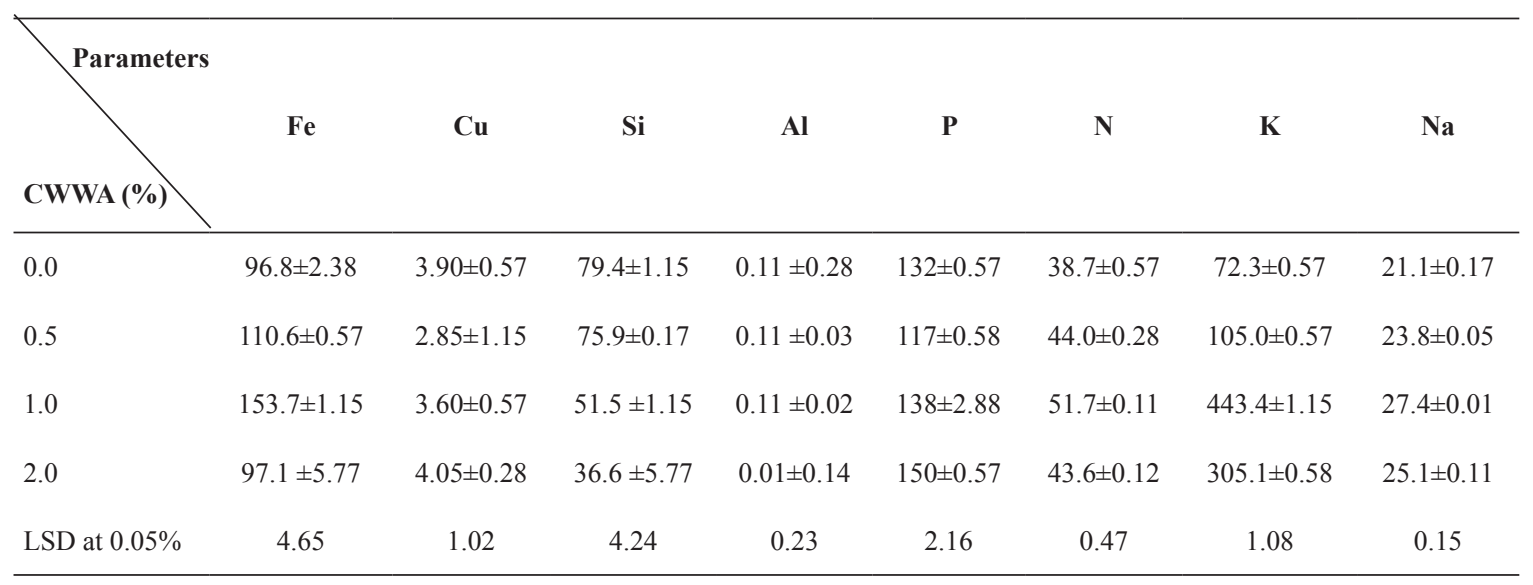

Results are means of three replicates \pm SE. 
In plants, the physiological and metabolic processes are always influenced by the accumulation of heavy metals and the photosynthetic apparatus seems to be the most sensitive for heavy metal stress among various parameters (MacFarlane \& Burchett, 2001 and Zhang et al., 2007). The photosynthetic activity is often inhibited when the plants are exposed to heavy metals (Huang \& Wang, 2010). In the present study, the application of CWWS sludge positively affected the photosynthetic pigment contents (chlorophylls $a, b$ and carotenoids) in leaves of the plants under study. The stimulatory effects of CWWS on chlorophylls $a$ and $b$ contents might be attributed to their enhanced biosynthesis. Moreover, this might be also due to that CWWS application increased the number of green leaves and leaf area per plant and enhanced macro- and micro-nutrient elements in soil, where both are essential for plant growth and photosynthetic pigments (Kalaji et al., 2018). A deficiency in nutrients strongly influences the photosynthetic apparatus, mainly by disrupted synthesis of key photosynthetic components (Kalaji et al., 2014 and Jin et al., 2015). In this connection, chlorophyll $a$ fluorescence is considered as a reliable technique for the assessment of electron transport and related photosynthetic processes (Goltsev et al., 2016 and Kalaji et al., 2017). The changes in carotenoids were significantly higher than that of the control in the plants grown the soil amended with the different levels of ceramic sludge. These results also agreed to a wide extent with those of other authors showing enhancement of carotenoids under the influence of different stresses (Sacca et al., 2003 and ElAraby, 2006). Increased contents of carotenoids under cadmium stress have been also reported in Zea mays (Drazkiewicz \& Baszynski, 2005). On the other hand, elevated carotenoid contents under stress are mainly due to their higher tolerance and protective role for chlorophylls (Orcutt \& Nilsen, 2000).

In the present work, the level of lipid peroxidation product malondialdehyde (MDA) was significantly increased on application of ceramic sludge (Table 4). Increased levels of MDA under heavy metal stress have been reported in previous studies, such as in Eichhornia crassipes (Hu et al., 2007) and Spartina alterniflora (Chai et al., 2014) under $\mathrm{Cu}$ stress, and in Kandelia obovata under Zn stress (Zhao \& Zheng, 2015). The increase in MDA content might be due to an increase in some reactive oxygen species (ROS) that are continuously formed as by-products of normal metabolic processes in plant tissues and are enhanced under stress conditions.

The results of the present work also showed trends of significantly enhanced contents of sucrose and proline, in response to CWWS, as compared with corresponding controls. The increased sucrose and proline levels were allied with concomitantly decreased contents of soluble sugars and soluble proteins. These results might propose that the signaling strategy in the common bean cultivar under investigation, for soil amendment with CWWS, would be mainly related to elevation of sucrose and proline. However, increased production of compatible solutes is a key aspect of the cell osmotic regulation to balance water potential and stabilize the structure of biological macromolecules on being exposed to oxidative stress ( $\mathrm{Li}$ et al., 2010 and Chai et al., 2014). The increased proline level under the influence of CWWS agreed with the results of Huang \& Wang (2010) who reported high proline accumulation in the leaves of Kandelia obovata exposed to various heavy metals. In the present work, the decreased soluble protein contents of common bean, that have resulted with CWWS application (Table 4), agreed to a certain extent with the results of Guo et al. (2007), and Sun et al. (2009) who recorded decreased leaf soluble protein contents with increasing Cd levels.

Excessive heavy metals in plants can impair important physiological/ biochemical processes by inducing generation of ROS, and disturbing the anti-oxidative systems and electron transport chains (Anjum et al., 2013). In order to relieve the stress, plants develop antioxidant enzymes for eliminating ROS (Wang \& Zhou, 2006). In the present study, antioxidant enzymes responded differently under the application of CWWS. Thus, catalase (CAT) and polyphenol oxidase (PPO), showed significantly enhanced activities with increasing the amended ratio of the sludge, whereas superoxide dismutase (SOD), ascorbate oxidase (ASO) and ascorbate peroxidase (APX) activities exhibited generally opposite trends (Table 5).

In addition to oxidative enzymes, we have also assessed the contents of non-enzymatic antioxidants (Table 6). Ascorbic acid (AsA) and total phenol contents were significantly increased, 
as compared with those of corresponding controls, in response to soil amendment with CWWS. The increase in AsA contents might be partially attributed to the corresponding decreases in the activity of ascorbate oxidase (ASO) and ascorbate peroxidase (APX) enzymes (Table 4). In this respect, AsA is known to act for detoxification of radicals via one electron reduction with formation of the unreactive and "harmless" monodehydroascorbate (MDHA) radical, for removal of $\mathrm{H}_{2} \mathrm{O}_{2}$ and for photoprotection of photosynthesis by violaxanthin de-epoxidase (VDE) enzyme. This enzyme uses ascorbate as a reductant, as well as for reduction of $\mathrm{Fe}^{3+}$ to facilitate $\mathrm{Fe}$ uptake and with glutathione it acts to maintain the cellular redox status (Smirnoff, 2011 and Badu-Boateng et al., 2017). Phenolic compounds also exhibit antioxidant activities through inactivating lipid free radicals or preventing decomposition of hydroperoxides into free radicals in addition to decreasing membrane fluidity (Pokorny et al., 2001 and Gaballah et al., 2007).

In the present study, glutathione (GSH) contents of these plants were significantly below the control level and its decrease would be simply predicted to result from either a decreased biosynthesis and/ or enhanced degradation (Noctor \& Foyer, 1998). meanwhile, our results that showed attenuated levels of GHS, on CWWS application, might be assumed to result from over consumption in the synthesis of phytochelatins (PCs), thus leading to heavy metal detoxification as well as maintenance of ionic homeostasis (Hirata et al., 2005 and Yadav, 2010). This mechanism of heavy metal tolerance in plants has strongly suggested that GSH should not be limiting and perhaps is not sufficient alone to support the complex mechanism under heavy metal induced stress (Yadav, 2010 and Namdjoyan et al., 2016). In addition, Xiang et al. (2001) stated that elevation of GSH did not always correlate with enhanced tolerance to heavy metals.

In the present study, the contents of $\mathrm{P}, \mathrm{N}$ and $\mathrm{K}$ were higher in the plants grown in the soil amended with ceramic sludge of $P$. vulgaris and it is likely due to the higher content of these metals in the ceramic amended soil. Iron $(\mathrm{Fe})$ and copper $(\mathrm{Cu})$ nearly increased at all levels of sludge used. Fe is essential for the survival and proliferation of all plants. The increase in micronutrients as Fe may be a defense mechanism employed by plants to cope with heavy metal stress in contaminated soil. On the other hand, Iron (Fe), zinc ( $\mathrm{Zn})$ and copper
$(\mathrm{Cu})$ are associated with photosynthesis (Porra, 2002). Generally, the results of this study provides evidence for a beneficial effect of ceramic sludge application at $1 \%$ level for common bean plants cultivated in virgin sandy soil.

\section{References}

Adamcová, D., Vaverková, M.D. and Břoušková, E. (2016) The toxicity of two types of sewage sludge from wastewater treatment plant for plants. J. Ecol. Eng. 17, 33-37.

Anjum, N.A., Ahmad, I., Rodrigues, S.M., Henriques, B., Cruz, N., Coelho, C., Pacheco, M., Duarte, A.C. and Pereira, E. (2013) Eriophorum angustifolium and Lolium perenne metabolic adaptations to metalsand metalloids-induced anomalies in the vicinity of a chemical industrial complex. Environ. Sci. Pollut. Res. 20, 568-581.

Antolín, M.C., Muro, I. and Sánchez-Díaz, M. (2010) Application of sewage sludge improves growth, photosynthesis and antioxidant activities of nodulated alfalfa plants under drought conditions. Environ. Exp. Bot. 68(1), 75-82.

Badu-Boateng, C., Pardalaki, S., Wolf, C., Lajnef, S., Peyrot, F. and Naftalin, R.J. (2017) Labile iron potentiates ascorbate-dependent reduction and mobilization of ferritin iron. Free Rad. Biol. Med. 108, 94-109.

Bates, L.S., Waldren, R.P. and Tear, I.D. (1973) Rapid determination of free proline for water-stress studies. Plant and Soil, 39, 205-207.

Brown, E.J., Khoder, H., Hider, C.R. and Rice-Evans, C.A. (1998) Structural dependence of flavonoid interactions with $\mathrm{Cu}^{+2}$ ions: Implications for their antioxidant properties. Biochem. J. 330(3), 11731178.

Chai. M.W., Shi, F.C., Li, R.L. and Shen, X.X. (2014) Heavy metal contamination and ecological risk in Spartina alterniflora marsh in intertidal sediments of Bohai Bay, China. Mar. Pollut. Bull. 84(1-2), $115-$ 124.

Chaoui, A., Mazhoudi, S., Ghorbal, MH. and El Ferjani, E. (1997) Cadmium and zinc induction of lipid peroxidation and effects on antioxidant enzyme activities in bean (Phaseolus vulgaris L.). Plant Sci. 127, 139-147. 
Chapman, H.D. and Pratt, P.F. (1961) "Method of Analysis for Soil, Plants and Waters". University of California, Agri Sci., Berkeley, 309 p.

Chatterjee, J. and Chatterjee, C. (2000) Phytotoxicity of cobalt, chromium and copper in cauliflower, Environ. Pollu. 109(1), 69-74.

Chen, Y., Cao, X.D., Lu, Y. and Wang, X.R. (2000) Effects of rare earth metal ions and their EDTA complexes on antioxidant enzymes of fish liver. Bull. Environ. Contam. Toxicol. 65, 357-365.

Daughaday, W.H., Lowry, O.H., Rosebrough, N.J. and Fields, W.S. (1952) Determination of cerebrospinal fluid protein with the folin phenol reagent. J. Lab. Clin. Med. 39, 663-665.

Diallinas, G., Pateraki, I., Sanmartin, M., Scossa, A., Stillianou, E., Panopoulos, N.J. and Kanellis, A.K. (1997) Melon ascorbate oxidase: Cloning of a multigen family, induction during fruit development and repression by wounding. Plant Mol. Biol. 34, 759-770

Drazkiewicz, M. and Baszynski, T. (2005) Growth parameters and photosynthetic pigments in leaf segments of Zea mays exposed to cadmium, as related to protection mechanisms. J. Plant Physiol. 162, 1013-1021.

El-Araby, M.I. (2006) Evaluation of stress tolerance in four maize hybrids under influence of drought, salinity and both. El-Minia Sci. Bull. 17(2), 228-259.

Elias, S.H., Mohamed, M., Ankur, A.N., Muda, K., Hassan, M.A.H.M., Othman, M.N. and Chelliapan, S. (2014) Water hyacinth bioremediation for ceramic industry wastewater treatment-application of rhizofiltration system. Sains Malaysiana, 43(9), 1397-1403.

Fairbairn, N.J. (1953) "A Modified Anthrone Reagent". Chem. Ind., London Vol. 4, pp. 86-86.

Filippou, P., Bouchagier, P., Skotti, E. and Fotopoulos, V. (2014) Proline and reactive oxygen/ nitrogen species metabolism is involved in the tolerant response of the invasive plant species Ailanthus altissima to drought and salinity. Environ. Exp. Bot. 97, 1-10.

Gaballah, M.S., Ouda, S.A., Mandour, M.S. and Rady, M.M. (2007) Predicting the role of antioxidants and irrigation on sunflower yield grown under saline conditions. International Journal of Natural and Engineering Sciences, 1, 5- 10.

Goland-Goldhirsh, A. (2006) Plant tolerance to heavy metals, a risk for food toxicity or means for food fortification with essential metals: The Allium schoenoprasum model. In: "Soil and Water Pollution Monitoring, Protection and Remediation", I. Twardowska, H.E. Allen and M.M. Haggblom (Eds.), pp. 479-486. Spinger, Amsterdam.

Goltsev, V.N., Kalaji, H.M. and Paunov, M. (2016) Variable chlorophyll fluorescence and its use for assessing physiological condition of plant photosynthetic apparatus. Russ. J. Plant Physiol. 63, 869-893.

Griffiths, O.W. (1980) Determination of glutathione and glutathione disulfide using glutathione reductase and 2-vinylpyridine. Anal Biochem. 106, 207-212.

Guo, H., Liu, A.H.,Ye, M., Yang, M. and Guo, D.A. (2007) Characterization of phenolic compounds in the fruits of Forsythia suspensa by high peformance liquid chromatography with electrospray ionization tandem mass spectrometry. Rapid Commun. Mass. Spectrom. 21, 715-729.

Hernández, J.A., Ferrer, M.A., Jiménez, A., Barceló, A.R. and Sevilla, F. (2001) Antioxidant systems and $\mathrm{O}_{2}^{-} / \mathrm{H}_{2} \mathrm{O}_{2}$ production in the apoplast of pea leaves. Its relation with salt-induced necrotic lesions in minor veins. Plant Physiol. 127, 817-831.

Hirata, K., Hirata, N. and Tsuji, K. (2005) Miyamoto biosynthetic regulation of phytochelatins, heavy metal-binding peptides. J. Biosci Bioengine. 100, 593-599.

Hossain, M.A. and Fujita, M. (2010) Evidence for a role of exogenous glycine betaine and proline in antioxidant defense and methyl-glyoxal detoxification systems in mung bean seedlings under salt stress. Physiol. Mol. Biol. Plants, 16, 19-29.

Hu, X., Jiang, M., Zhang, J., Zhang, A., Lin, F. and Tan, M. (2007) Calcium-calmodulin is required for abscisic acid-induced antioxidant defense and functions both upstream and downstream of $\mathrm{H}_{2} \mathrm{O}_{2}$ production in leaves of maize (Zea mays) plants. New Phytol. 173: 27-38.

Huang, G.Y. and Wang, Y.S. (2010) Physiological 
and biochemical responses in the leaves of two mangrove plant seedlings (Kandelia candel and Bruguiera gymnorrhiza) exposed to multiple heavy metals. J. Hazard Materials, 182(1-3), 848-854.

Jin, X., Yang, G., Tan, C. and Zhao, C. (2015) Effects of nitrogen stress on the photosynthetic $\mathrm{CO}_{2}$ assimilation, chlorophyll fluorescence, and sugarnitrogen ratio in corn. Sci Rep. 5, 9311. Doi: 10.1038/ srep09311.

Kalaji, H.M., Oukarroum, A. and Alexandrov, V. (2014) Identification of nutrient deficiency in maize and tomato plants by in vivo chlorophyll a fluorescence measurements. Plant Physiol. Biochem. 81, 16-25.

Kalaji, H.M., Schansker, G. and Brestic, M. (2017) Frequently asked questions about chlorophyll fluorescence. Sequel. Photosynth. Res. 132, 13-66.

Kalaji, H.M., Bąba, W., Gediga, K., Goltsev, V., Samborska, I.A., Cetner, M.D., Dimitrova, S., Piszcz, U., Bielecki, K., Karmowska, K., Dankov, K. and Bąba, K.A. (2018) Assessments of levels, potential ecological risk, and human health risk of heavy metals in the soils from a typical county in Shanxi Province, China. Photosynthesis Res. 136, 329-343.

Kampfenkel, K., Van Montagu, M., and Inze', D. (1995) Extraction and determination of ascorbate and dehydroascorbate from plant tissue. Anal Biochem. 225, 165-167.

Kar, M. and Mishra, D. (1976) Catalase, peroxidase and polyphenol oxidase activities during rice leaf senescence. Plant Physiol. 57, 315-319.

Koricheva, J., Roy, S., Vranjic, J.A., Haukioja, E., Hughe, P.R. and Hanninen, O. (1997) Antioxidant responses to simulated acid rain and heavy metal deposition in brich seedlings. Environ. Pollut. 95, 249-258.

Kotb, E.A., Moursy, A.A.A. and Noby, M.F.A. (2012) Response of peppermint (Mentha piperita L.) grown on different sources of waste water. $J$. Rad. Res. Appl. Sci. 5(2), 247-256.

Lavid, N., Schwartz, A., Yarden, O. and Tel-Or, E. (2001) The involvement of polyphenols and peroxidase activities in heavy metal accumulation by epidermal glands of the water lily (Nymphaeaceae). Planta, 212, 323-331.
Li, B.J., Xiang, C., Yang, X.W., Wu, L.J., Guo, D.A. and Ye, M. (2010) Fingerprint analysis of Tongmai granule by HPLC-MS technique. Acta Pharm. Sin. 45, 1410-1414.

MacFarlane, G.R. and Burchett, M.D. (2001) Photosynthetic pigments and peroxidase activity as indicators of heavy metal stress in the grey mangrove Avicennia marina (Forsk.) Vierh. Marine Pollu. Bull. 42(3), 233-240.

Makkar, H.P.S., Blümmel, M., Borowy, N.K. and Becker, K. (1993) Gravimetric determination of tannins and their correlations with chemical and protein precipitation methods. J. Sci. Food and Agric. 61(2), 161-165.

Marklund, S. and Marklund, G. (1974) Involvement of the superoxide anion radical in the autoxidation of pyrogallol and a convenient assay for superoxide dismutase. Eur. J. Biochem. 47, 469-474.

McBride, M.B. (2003) Toxic metals in sewage sludgeamended soils: Has promotion of beneficial use discounted the risks? Adv. Environ. Res. 8, 5-19.

Metzener, H., Rau, H. and Senger, H. (1965) Untersuchung enzursyn chronisier barteiteinzelner pigment-Mangel-Mutantebvon Chlorella. Planta (Berl.), 65, 186-194.

Minotti, G. and Aust, S.D. (1987) The requirement for iron (III) in the initiation of lipid peroxidation by iron (II) and hydrogen peroxide. J. Biol. Chem. 262(3), 1098-1104.

Muchuweti, M., Birkett, J.W., Chinyanga, E., Zvauya, R., Scrimshaw, M.D. and Lester, J. (2006) Heavy metal content of vegetables irrigated with mixture of wastewater and sewage sludge in Zimbabwe: Implications for human health. Agric. Ecosys. Environ. 112, 41-48.

Mukheriee, S.P. and Choudhuri, M.A. (1983)Implication of water stress-induced changes in the level of endogenous ascorbic acid and hydrogen peroxide in Vigna seedling. Physiol Plant. 58, 166-170.

Nagajyoti, P.C., Lee, K.D., Sreekanth ,T.V.M., Nagajyoti, P.C. (2010) Heavy metals, occurrence and toxicity for plants: a review. Environ. Chem. Letters, 8(3), 199-216.

Namdjoyan, S.H., Namdjoyan, S.H. and Kermanian, 
H. (2016) Phytochelatin synthesis and responses of antioxidants during arsenic stress in Nasturtium officinale. Russ.J. Plant Physiol. 63(6), 739-748.

Noctor, G. and Foyer, C.H. (1998) Ascorbate and glutathione: Keeping active oxygen under control. Annu. Rev. Plant Physiol. Plant Mol. Biol. 49, 249279.

Orcutt, D.M. and Nilsen, E.T. (2000) Salinity stress. In: "Physiology of Plants under Stress: Soil and Biotic Factors", pp. 177-236. John Wiley and Sons, Inc., New York, USA.

Page, AL., Miller, R.H. and Keeney, D.R. (1982) "Methods of Soil Analysis", part 2: Chemical and Microbiological Properties, $2^{\text {nd }}$ ed. American Society of Agronomy and Soil Science Society of America (Special Publication No 9), Madison, Wisc.

Pokorny, J., Pokorny, J., Yanishlieva, N. and Gordon, M.H. (2001) "Introduction in Antioxidants in Food: Practical Application", pp. 1-3. Wood Head Publishing Ltd, Cambridge.

Porra, R.J. (2002) The chequered history of the development and use of simultaneous equations for the accurate determination of chlorophylls $a$ and $b$. Photosynthesis Research, 73, 149-156.

Rahman, M.F., Islam, M., Begum, M.C., Kabir, A.H. and Alam, M.F. (2017) Genetic variation in cadmium tolerance is related to transport and antioxidant activities in field peas (Pisum sativum L.). J. Arch. Agron. Soil Sci. 63(4), 578-585.

Ranganayakulu, G.S., Veeranagamallaiah, G. and Sudhakar, C. (2013) Effect of salt stress on osmolyte accumulation in two groundnut cultivars (Arachis hypogaea L.) with contrasting salt tolerance. Afr. $J$. Plant Sci. 12, 586-592.

Sacca, E., Demczuk, A. and Michalski, T. (2003) Responses of maize (Zea mays L.) to rimsulfuron under salt conditions. Acta Societatis Botanicorum Poloniae, 72(2), 93-98.

Singh, R.P. and Agrawal, M. (2008) Potential benefits and risks of land application of sewage sludge. Waste Manag. 28, 347-358.

Smirnoff, N. (2011) Vitamin C: The metabolism and functions of ascorbic acid in plants. Adv. Bot. Res. 59, 108-177.
Snedecor, G.W. and Cochran, W.G. (1980) "Statistical Methods", $5^{\text {th }}$ ed. Iowa State University Press, Ames, Iowa, USA, 276p.

Sun, Y.B., Zhou, Q.X., Wang, L. and Liu, W.T. (2009) Cadmium tolerance and accumulation characteristics of Bidens pilosa $\mathrm{L}$. as a potential Cdhyperaccumulator. J. Hazard. Mater. 161, 808-814.

Tian, K., Huang, B., Xing, Z. and Hu, W. (2017) Geochemical baseline establishment and ecological risk evaluation of heavy metals in greenhouse soils from Dongtai. China. Ecol. Indicat. 72, 510-520.

Wang, M. and Zhou, Q. (2006) Effects of herbicide chlorimuron-ethyl on physiological mechanisms in wheat (Triticum aestivum L.). Ecotoxicol. Environ. Saf. 64, 190-197.

Xiang, C., Werner, B.L., Christensen, E.M. and Oliver, D.J. (2001) The biological functions of glutathione revisited in Arabidopsis transgenic plants with altered glutathione levels. Plant Physiol. 126, 564 574.

Yadav, S.K. (2010) Heavy metals toxicity in plants: An overview on the role of glutathione and phytochelatins in heavy metal stress tolerance of plants. South Afr. J. Bot. 76(2), 167-179.

Zhang, F.Q., Wang, Y.S., Lou, Z.P. and Dong, J.D. (2007) Effect of heavy metal stress on anti-oxidative enzymes and lipid peroxidation in leaves and roots of two mangrove plant seedlings (Kandelia candel and Bruguiera gymnorrhiza). Chemosphere, 67(1), 44-50.

Zhao, H. and Zheng, W. (2015) Effect of zinc stress on growth and antioxidant enzyme responses of Kandelia obovata seedlings. Toxicol. Environ. Chem. 97, 1190-1201.

Zia, M.H., Watts, M.J., Niaz, A., Middleton, D.R.S. and Kim A.W. (2017) Health risk assessment of potentially harmful elements and dietary minerals from vegetables irrigated with untreated wastewater,. Pakistan Environ. Geochem. Health, 39, 707-728.

Received 17/10/2018; accepted 27/1/2019) 


\section{إستجابة نبات الفاصوليا للمعاملة بحمأة مياه صرف صناعة السير اميك}

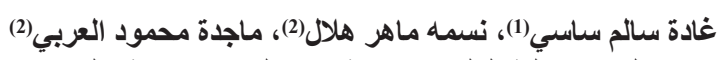

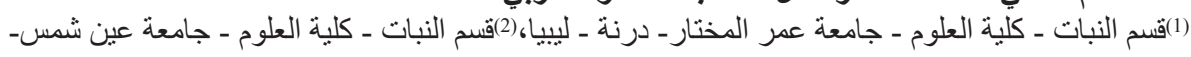
القاهرة - مصر.

تهدف هذه الدراسة لفحص الإستجابات الفسيولجية والكيموأحيائية لنبات الفاصوليا للسلالة الزراعية فالنتينو و وللك للنباتات المنزر عة لمدة 30 يوما في التربة الرملية البكات البكر (Phaseolus vulgaris L.cv. Valentine)

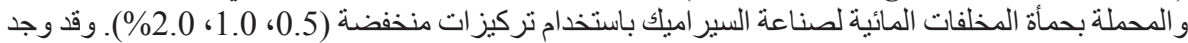

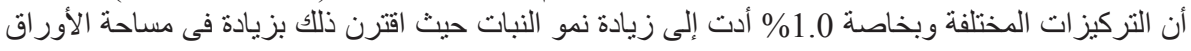

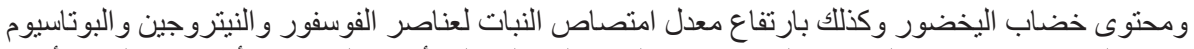

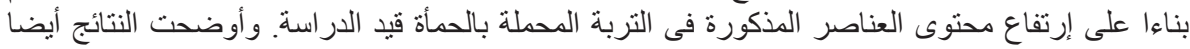

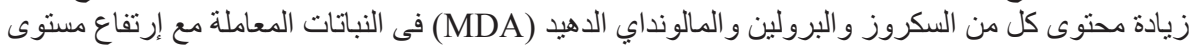

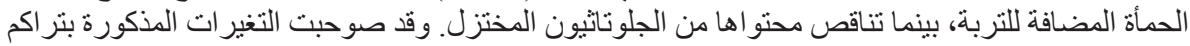

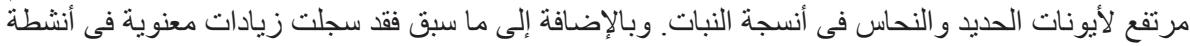

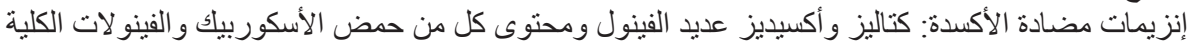

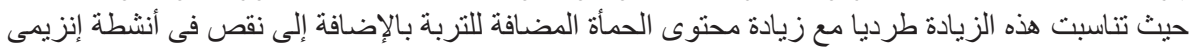
أكسيديز وبير أكسيديز الأسكوربيك. 